\title{
Identification of Gathering Space in Pekan Labuhan
}

\author{
Morida Siagian ${ }^{1, *}$ Samsul Bahri ${ }^{2}$ Rudolf Sitorus ${ }^{3}$ \\ ${ }^{1,2,3}$ Department of Architecture, Faculty of Engineering, Universitas Sumatera Utara, Jl. Universitas Kampus USU \\ Medan 20155 \\ Email:pohontepiair@gmail.com,morida@usu.ac.id
}

\begin{abstract}
Understanding globalization and modernization has always been related to capitalism which in the end tends to weaken the social and social relations between the peoples of the city who have been living in it. Meanwhile, at various points in the city's growth centre it is still necessary to elaborate the forces formed so that the presence of modern spaces in a city does not destroy the activities, identities and lifes of local people. Social space is considered as solutions to problems and able to highlight urban public spaces. Through qualitative research, this research tries to identify social spaces created by the social relations of Chinese and Malay communities in the Pekan Labuhan area. The research is conducted by observing the spaces and activities in the gathering space and conducting in-depth interviews with those both people who use the space. The established social relations between those two communities have established new spaces that can nurture Pekan Labuhan's identity.
\end{abstract}

Keywords: Gathering Space, Pekan Labuhan, Social Relation, Social Space.

\section{INTRODUCTION}

Wirth's signal and speech, as reported by Barker [1] stated that capitalism-based globalization is causing a loss of cultural diversity. City life is slowly shutting down social-relations between communities. The development of the application of science about social relations experienced by people in the city area is still minimal from the attention of the architects. This research on space-relationships is about the space generated by the social-relationships of people who coexist in one region.

The concept of space in Lefebvre's The Production of Space is a way to explain the process of destruction of a society [2]. He articulated that the phenomenon of activity that occurs in urban areas is a phenomenon of space not only physically but also socially. But there is another phenomenon in the space, namely the gap between the interests of the city community and the system created by capitalists. The conflict between the two parties lies in the utilization of publicly owned use of living space and the exchange value of capitalism brought by capitalists. These spaces have always been contradicted by the qualitative space that the city community has on the one hand and the quantity space under the influence of capitalists on the other hand. The contradiction of these two interests occurs when the qualitative value owned by the use value space is manipulated by the quantitative value of the exchange value space. That is why there is attraction about modern spaces in urban areas that are always fascinating in contradictions with local spaces. Lefevbre's critique of social-space is again seen as a reference in trying to provide solutions to problems and to highlight urban public spaces through 'social spaces' which also is also referred to as 'third spaces'.

Malay people who early used Pekan Labuhan area as a space for daily life that was worth using value of living. The evidence is seen from the spread of old houses as a place to live and the establishment of Osmani Mosque, the oldest mosque in Medan as a place to worship and the royal balariung of Deli Sultanate as the place of sultanate area. Malay influences are more complete when they are able to bring their spiritual life and customs to the social environment. This makes ethnic Malays host their own regions, both from the cultural, social and societal sectors.

Migrant Chinese took advantages of the area as a space for economic interest that has exchange value. The presence of Chinese people is able to dominate the strategic area and place them as holders of the economic sector. The early Malay houses in the strategic area have 
evolved into shop houses owned by Chinese on the South side Syahbuddin Yatim Street, the main street of the area (Figure 1). In addition to the strong families sector, they are also able to reduce the strength of Malay culture characterized by the existence of Chinese-style buildings which shown by the existence of Vihara Tsui San Keng. It was built in 1839 as evidence of ethnic Chinese influence in the region.

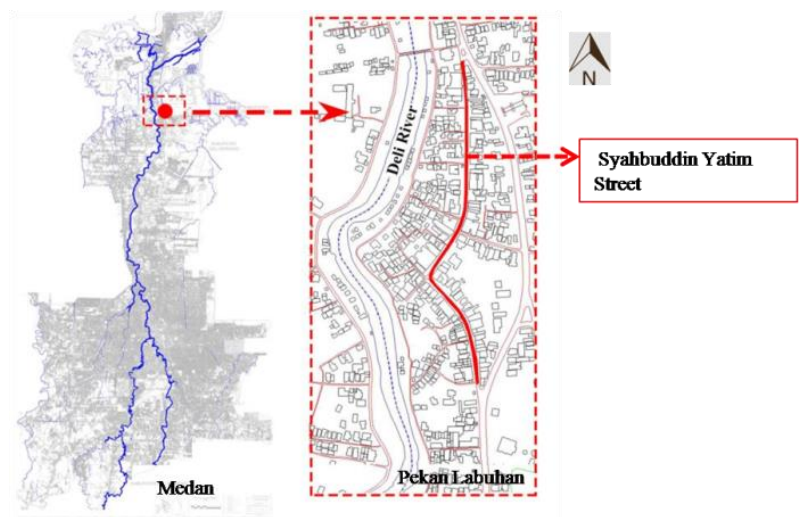

Figure 1 Location of Pekan Labuhan in Medan City

The qualitative blend of use value of living from Malays communities with quantitative exchange value from ethnic Chinese communities is coloring the Pekan Labuhan area. In the same place they interact each other in the activities of their families, and neighbors. The social interaction between Chinese and Malays people establishes harmonious neighbourhood and then it continues to create the social dynamics. Based on the social relationships that have been formed raises the question of whether those a relationship between the two ethnicities created in a new space, and how it is created those become the interest of the researchers to know the alleged new space that is able to preserve the history of Pekan Labuhan where the settlements are dominated by buildings of ethnic Chinese heritage but are still maintained by Malay domination.

\section{METHOD}

Social-space research in Pekan Labuhan, one of the old cities in Medan (Figure 1). This research uses qualitative research methodology. This methodology has two characteristics required. First, research in the form of case studies that focus on a particular phenomenon. Second, this explorative research emphasizes the understanding of a life that occurs in the society. Because of that, this research is not aimed at testing a hypothesis.

This research focuses on the phenomenon of social relations between Malays and Chinese people in creating the kindship in Pekan Labuhan area. The phenomenon is then reviewed and identified to find out the process of establishing social-space from established social relationships. In addition, field observation studies were conducted to find and learn about the benefits of new spaces that have been formed so as to maintain the presence of both of group in Pekan Labuan area.

\section{RESULT AND DISCUSSION}

Lefebvre saw social space as a space of daily life where people interact with their daily activities. His thoughts are further expressed in space leotards such as "Spatial Practice", "Representation of Space (abstract space)" and "Representational of Space (social space)". Lefebrve explained that the forms of "Perceiving", Conceiving" and "Living" in space always exist in the urban life. According to him the lived space is resulted from a social-relationship and at the same time a pattern of regional formation that gives the possibility for social-space to occur. The reciprocal relationship between social relationships and space is inseparable. Gottdiener [3] describedthe term as: "It posesses the dual characteristic of being both a product of social relations and a producer of social relations."

If Lefebrve said that space is something important, then the concept of everyday life is a more important aspect. According to him, social space is a collection of relationships, not things. The center of attention is about how social-space is produced. Space is referred by Lefebrve as social space or space for daily life that has use value of living.

\subsection{History of Pekan Labuhan}

Pekan Labuhan area located in Medan is one of the areas of Deli Sultanate. However, the establishment of Deli Tobacco Plantation office in 1866 by the Dutch Colonial also brought the Chinese people into Pekan Labuhan. Since then, the area became a settlement of Chinese people who were working on Dutch plantations at the time. In the 19th century Pekan Labuhan experienced its by heyday. Chinese and Malay people who lived side by side in this area took benefits from the period, the pier and market center which located in this area. Until today it is crowded with visitors from various places who conduct trade activities. The increasing trade activities led the Chinese people in Pekan Labuhan to dominate the area. Meanwhile, Malays stick their activities by searing and trading fish. The increasing population of Chinese people in Pekan Labuhan prompted them to build Liat Sim Kong Vihara (Pekong) in 1872, and the Siu San Keng Vihara in 1890. The Liat Sim Kong Vihara is currently as the oldest temple in Medan, Indonesia.

Harmonious relations between Chinese and Malay people exists since that time and allow the children of those communities play around the Chinese-owned monasteries, swim together in the Deli River and play 
ball together on green fields. Friendships is built in everyday life for generations.

\subsection{Political incident}

In a political incident that occurred in 1965, the issue of the Indonesian Communist Party was developed in Indonesia. The communist group was regarded by the Indonesian government as a rebel group so the state ordered the group to be annihilated. This issue also further divided Indonesians into two groups, namely the representation of indigenous peoples of Indonesia and non-indigenous groups as representatives of tribes from outside Indonesia.

The Chinese people in Pekan Labuhan are considered pro-communist groups so there was a criminalization by the natives (including Malays) against them. The criminalization resulted Chinese people evacuate and some of them decided to move to other areas that might kept them safe from criminalization. The moment of the incident has subsided. However, displaced people decided to return to Labuhan. They rebuilt a business that had stalled and also rebuilt good social relations with the Malay community in the region. In the 1970s inter-community relations in Pekan Labuhan slowly returned harmoniously.

The incident of political division occurred again in 1998. At that time the Indonesia was undergoing a period of reform. In those days, conflicts between indigenous and non-indigenous occurred in various regions. The reform event also took place in Pekan Labuhan. It threated the existence of China and their trading businesses. Indigenous groups are provoked to reject China's presence in their environment. Groups of youth organizations, political parties and thugs as well as the provoked community carried out looting throughout the shophouses of the Chinese people.

The looting of these items has left Chinese people fearful and traumatised. Those who were afraid then evacuaded to the Vihara building to save themselves by carrying important files. After the incident, the Chinese then sold their shophouses for a low price to the Malays and then moved to another area.

\subsection{Living in Pekan Labuhan area}

Pekan Labuhan began with the image of the royal area of the Sultanate of Deli marked which was by the Balariung Sultanate of Deli, houses of worship, and rows of Malay settlements. Those buildings reinforced the image of this area as Kampung Melayu. This area which was before as the Malay village that was undergoing the process of the evolution of settlements due to the presence of China migrants. Villages that were originally homogeneous turned into heterogeneous ones, both in social and economic activities.

Heterogeneity in the old city area is experiencing ups and downs. The heyday occurred when Dutch colonialists and ethnic Chinese concentrated their economic activities in this area as a hub of crowds and international trade areas. Then, when the port area moved to Belawan Port, the area became increasingly desolate to almost cripple economic activities. Commonly, the city area is characterized with private space and lack of interaction between residents. However, the centre of Pekan Labuhan area is heterogeneous which has strong relationships and interaction between cross-ethnic people. The area is for all people. The number of relatives and the inherent identity of their birth place, and lifely interaction between cross-ethnic citizens makes them feel at home in this place. The people who live here are mix of indigenous Malay settlers and China migrants. Crossgenerational communities have been living in the region for hundreds years.

\subsection{Social Relation between Malay and Chinese People}

The beginning of a social relationship is the interaction activity of two or more people involving their own attitudes, values and expectations. In the context of the social relations that took place in Pekan Labuhan between local Malays and migrants China. Since the beginning of the arrival of ethnic Chinese to this region the familiarity was well established. Chinese were desperately trying to blend themselves with Malays. They wanted to be recognized for their existence to be Indonesians who they consider able to provide life expectancy rather than in their home country. Instead, Malays opened themselves up to the presence of migrants and were able to interact with foreign cultures in order to develop Malay culture and mission.

The relationship has created an outdoor socialization space between them without distinguishing ethnicities and religions. In traditional ceremonies, Malays brought their customs into daily life and become the foundation in conducting activities that concerns the both communities in the way of attitude, speech and treatment of others. The places of worship then became the central for religious activities and then also melt into cultural activities such as traditional birth ceremonies, marriages and deaths. The newcomer Chinese also brought their customs and their religion, Budha. Differences in ethnic and religious background between Malays and Chinese did not prevent them from visiting each other and interacting. 


\subsection{Gathering Space in Pekan Labuhan}

\subsubsection{Pekong (Vihara)}

The creation of space that occurred in this area are done by the Chinese and Malay peoples. Religious spaces in two Viharas buildings owned by the Chinese community and commercial space in Pekong Market create new spaces, called social spaces. The fate of the two societies depends on these. These spaces are space of agreement between China and Malay. The socialspace became a "security guarantee" for the Chinese people in carrying out religious needs on the two viharas. Viharas otherwise the social space are also high selling point attractions for the Malay business community in Syahbudin Yatim Street today (Figure 2).

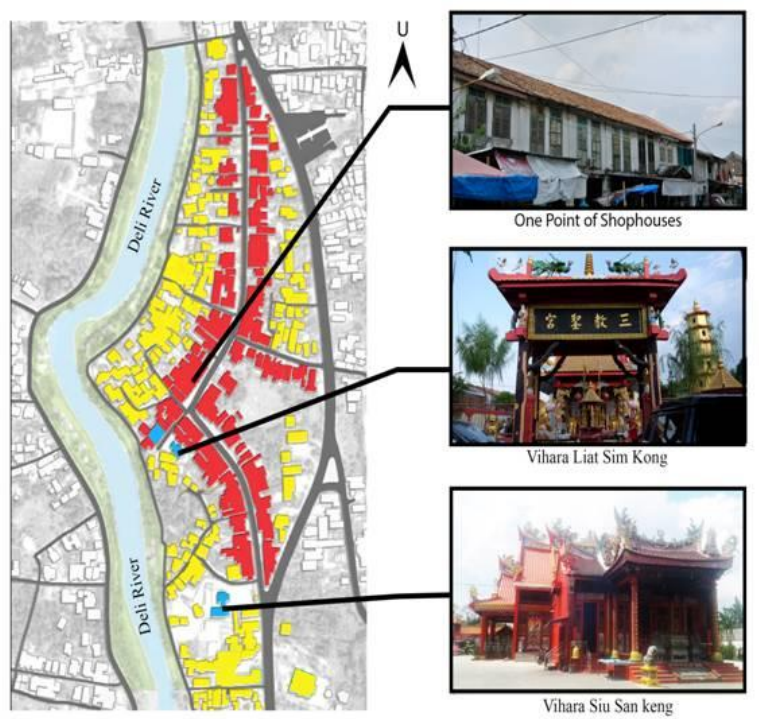

Figure 2 The location of viharas and shophouses

Political incidents in 1998 kept the majority of Chinese people moved out of the Pekan Labuhan area. Those who were initially majority, have been now become minority. They who still lived in area are Chinese families who live in two temple complexes to guard the buildings of worship. Currently more than 60 percent of the community in Pekan Labuhan is Malay, less than 40 percent are Batak, Chinese and Javanese people. Because of 1998 incident, the former Chinese shophouses are now controlled by the Malay people. After that, Pekan Labuhan became like a "dead city", the area that was once the economic and bustling centre of Medan city, and now a residential area of Malay families.

The existence of two viharas (Pekong) play roles in re-knitting relations between China and Malay. For them Pekongs are important space to live. The Chinese need safety for their Pekong, so they are open to Malays to participate in various events held. In addition, the Chinese people always give serious and sincere services to the Malay community (Figure 3). They are always serving the Malay community in the form of the share of food every New Year, being empathy to the important events experienced by the Malay and generous giving to the Malay community in Pekan Labuhan. The reason they do this is as a form of their application of worship to God, but the truth is to ensure that their two Pekong buildings are safe from the distraction of various groups. These Pekongs are creating Pekan Labuhan into "Sense of Place".
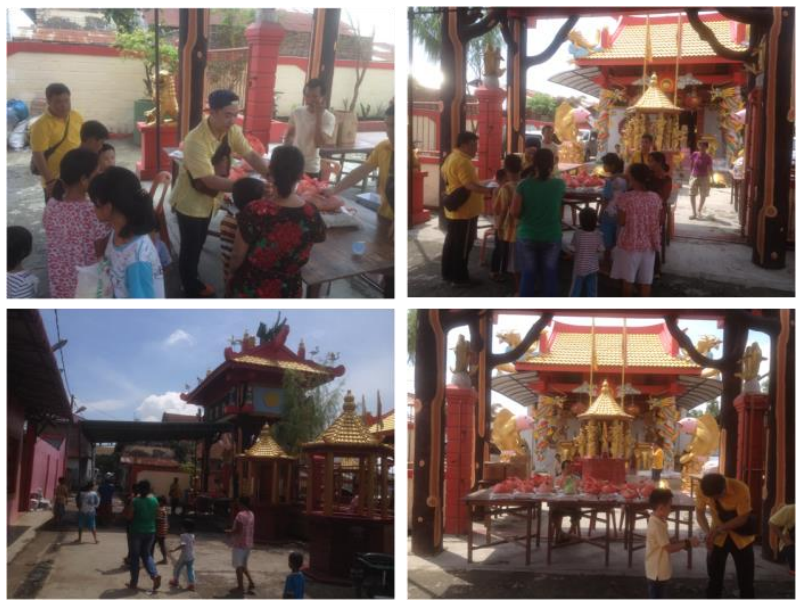

Figure 3 The Chinese people always give services to the Malay community

The Malays consider Pekong to be a space for good luck, because through the existence of Pekong every year they help Chinese community. In addition, the two Pekongs also are considered as spaces to earn money by giving their participation (both energy and effort) in the China's successful event that take place in Pekong.

\subsubsection{Pekong Market}

The existence of a row of old shopping houses that stretches along Syahbuddin Street is one of the elements of artifacts that still shows the memory and history of Pekan Labuhan area as a residential area and business center of Chinese society in the past. Today Malay community in the row of shophouses manages the morning market. The naming of the market is derived from the identity of the Vihara belonging to the Chinese people. The Pekong market became popular and successful to the people around the area.

Since 2001 the Malay community slowly built a morning market in the front of shophouses (Figure 4). They named the market "Pekong Market (Pasar Pekong)". They took advantage of Chinese Vihara identity. The morning market is still active and exists until today. The created space generates a regional identity. The social space that is produced from among the religious activities spaces of the Chinese people in the two Pekong viharas and the comercial space of the 
Malay community in Pekong Market are unique places in the area. This uniqueness also attract the Medan citizens from various points to come and enjoy the Pekan Labuhan area.

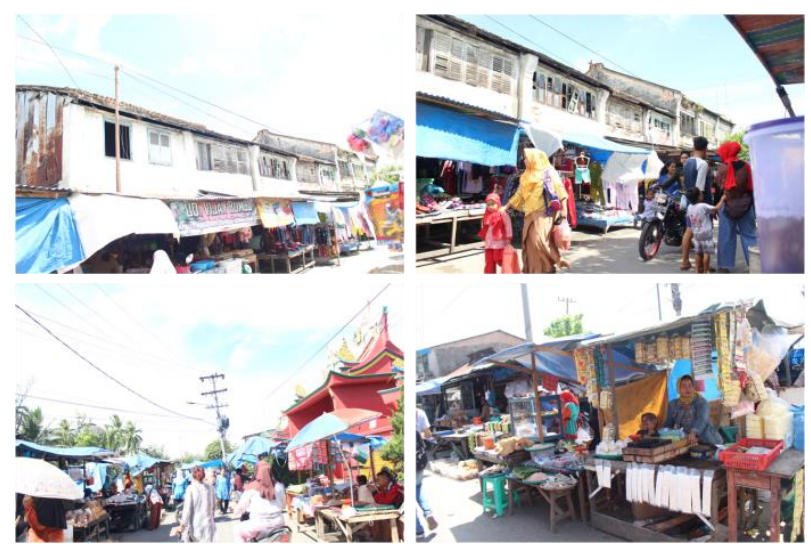

Figure 4 Pekong Market in the front of shophouses

Everyday, Pasar Pekong open between 06.00 and 12.00. Various household necessities can be purchased every day in this market. During the day, this street is also crowded by school children who just come home from and go to elementary school in the middle of the area.

\subsubsection{The main street, Syahbuddin Yatim Street}

Syahbuddin Yatim Street is used for economic activities and freight traffic lanes towards Belawan port. Various activities make this street be the centre of all community activities. The road is a main of Pekan Labuhan area. Trade activities by Chinese and Malay are along the street. As the shaft of the location it has an economic value (exchange value).

Syahbuddin Yatim Street is also an open space, which is a combination of exchange value and use value of living in the area. This space has been able to connect inter-ethnic interests in Pekan Labuhan area. The economic, social, religious and security needs of people living within the area happen here. Both communities are selling basic necessities along the street, such as vegetables, fruits and also serving coffee shop that open from morning to evening (Figure 5). The street are for socialization and interaction space so that there is a mutually beneficial relationship of the social aspect. It also usually used for weddings and cultural events so that they do not rent the spaces. The interaction struck on this old street is able to avoid the area from criminal acts.

In the afternoon the street is again crowded by the activities of the surrounding communities. Children's activities dominate the outdoor spaces, on the terrace and in the courtyard of the houses, residents visit each other and chat with neighbors. Thus Syahbuddin Yatim
Street became a unifying space for various interests of the people who are living in Pekan Labuhan area.

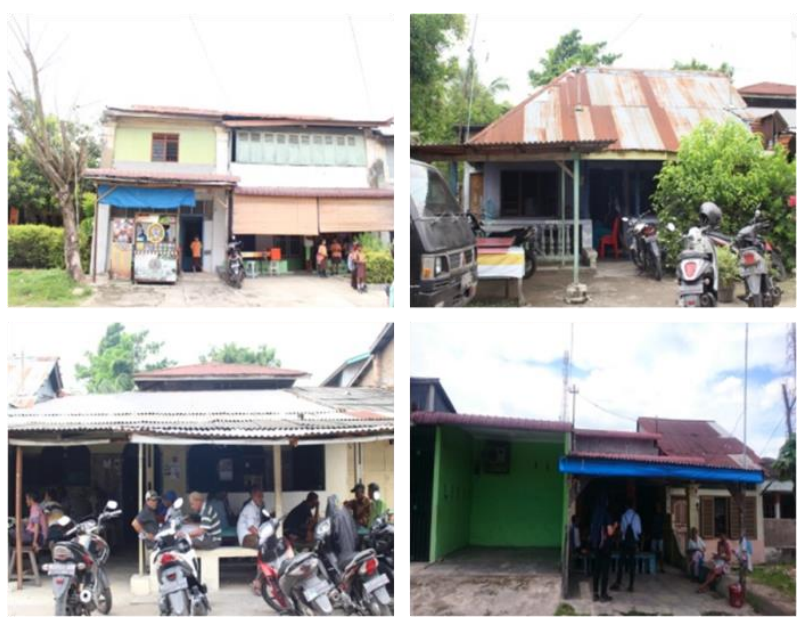

Figure 5 Community gathering space in Syahbuddin Yatim Street

\section{CONCLUSION}

The social relationship between communities, Chinese and Malays is well established since the beginning. Both groups are showing harmonious interaction, visiting between families, socializing and helping each in everyday life. More than that, the relationship is able be in facilitating cultural and religious events conducted in the area. Long-lasting social relationship that occurs in society creates a new spaces, that are referred as the "social space". They occur on spots of the Pekong Vihara and Pekong Market, and along the main street Syahbuddin Yatim Street. Those three social spaces then maintain the social relations between groups and creates the harmoniuos interaction. The social spaces become the tool for preserving the identity of the old area Pekan Labuhan. However, they are still thought to be destroyed if the government does not understand the phenomenon of the creating of spaces which has power to maintain the area's identity and existence.

\section{ACKNOWLEDGMENTS}

The authors gratefully acknowledge that the present research is supported by Universitas Sumatera Utara. The support is under the research grant TALENTA USU Skema Penelitian Dasar of Year 2018 Number: 299/ UN5.2.3.1/ PPM/ KP-TALENTA USU/ 2018. Thanks also to all those who have helped me in the process of research and the completion of this paper. 


\section{REFERENCES}

[1] Barker, Chris. Cultural studies: Theory and practice. Sage, 2003.

[2] Gottdiener, Mark. The social production of urban space. University of Texas Press, 2010.

[3] Lefebvre, Henri, The Production of Space, Blackwell Publishing, 1991. 